\title{
Reproductive Biology of Thrips Insect Species and Their Reproductive Manipulators
}

\author{
Wondimagegn Atilaw WOLDEMELAK \\ Department of Entomology, Hungarian University of Agriculture and Life Sciences, 1118 \\ Budapest, HUNGARY \\ e-mail: Wondimagegn.Atilaw.Woldemelak@hallgato.uni-szie.hu \\ ORCID ID: 0000-0002-9167-0100
}

\begin{abstract}
Some thrips species are considered as model insect organisms to study reproductive biology since some closely related (sub) species were mainly reproducing by arrhenotoky, thelytoky and in some rare cases as deuterotoky. As other insect species, thrips are associated with endosymbiotic bacteria and this bacteria has led to manipulating their reproductive biology. The main goal of this paper is to review the reproductive modes, potential reproductive manipulators and their strategies to change the reproductive biology of thrips species. Thrips species are reproducing through, arrhenotoky, thelytoky and deuterotoky. Wolbachia, Cardinium, Rickettsia and Spiroplasma have been detected in the reproductive organs of some thrips species and the most common insect reproductive manipulators by causing cytoplasmic incompatibility, thelytokous parthenogenesis, male killing and feminization.
\end{abstract}

Keywords: Apomictic, Automictic, Endosymbionts, Thrips and Wolbachia.

Woldemelak, W.A. (2021). Reproductive biology of thrips insect species and their reproductive manipulators. Journal of the Entomological Research Society, 23(3), 287-304. 


\section{INTRODUCTION}

The insect order Thysanoptera is composed of tiny insect species that are widespread throughout the world and in habitats ranging from forests, grasslands and scrublands to cultivated crops and gardens. The majority of thrips including almost all species of economic importance belong to the families Thripidae and Phlaeothripdae (Lewis, 1973).

Insect species in the order Thysanoptera exhibit haplodiploid sex determination mechanisms in the form of: (1) arrhenotoky (where virgin female produce haploid males and mated female produce diploid females). However, diploid male and polyploid female have been reported in Thrips tabaci (Lindeman) thrips species (Jacobson et al, 2013; Jacobson, Nault, Vargo, \& Kennedy, 2016) and diploid males and triploid females were reported in Heliothrips haemorrhoidalis (Bouche, 1833) (Nguyen, Spooner-Hart, \& Riegler, 2015) the parthenogenetic development of females, has independently evolved in several insect orders yet the study of its mechanisms has so far mostly focussed on haplodiploid Hymenoptera, while alternative mechanisms of thelytoky such as polyploidy are far less understood. In haplodiploid insects, thelytoky can be encoded in their genomes, or induced by maternally inherited bacteria such as Wolbachia or Cardinium. Microbially facilitated thelytoky usually results in complete homozygosity due to gamete duplication and can be reverted into arrhenotoky, the parthenogenetic development of males, through treatment with antibiotics. In contrast, genetically encoded thelytoky cannot be removed and may result in conservation of heterozygosity due to gamete fusion (Bouche, 1833).

Genetically inherited sex determinations such as automictic and apomictic thelytoky have displayed in the parthenogenetic thelytokous reproduction biology of insect species. (1) Automictic thelytokoy sex determination follows a meiotic cell division process. In this system, the new diploid female gamete has resulted from a single meiotically dividing cell, crossing over during meiosis retained (producing recombinant chromosomes) and diploid eggs produced by the fusion of sister or non-sister nuclei. (2) Apomictic thelytoky sex determination follows only a mitotic cell division process and it does not require the fusion of meiotic products, crossing over during meiosis not retained. The formation of eggs through a complete suppression of meiosis causes genetically identical progeny to their mother (Mogie, 1986; Engelsta, 2008; Heimpel \& Boer, 2008). These two sex determination mechanisms are most likely common in the Hymenoptera insect species such as Sawfly Strongylogaster maculata, cynipid Neoretus baccarum and ant Oecophylla longinoda and ant Wasmannia auropunctata, Micromalthus, cecidomyid midges and cynipid wasps (Stenberg \& Saura, 2009; Van Wilgenburg, Driessen, \& Beukeboom, 2006; Rabeling \& Kronauer, 2013). Although, these two sex determination has not been reported in the Thysanoptera insect species.

Endosymbionts are common in arthropod insect species and particularly known to occur in some thrips species (Table 2) (Stouthamer, Luck, \& Hamilton, 1990; Arakaki, Miyoshi, \& Noda, 2001). They are reproducing and detecting in the reproductive organs of their hosts. Research reports revealed that sexual distortion in arthropod has caused by endosymbiotic bacteria, nematode, and viruses (Kageyama, Narita, Watanabe, 2012). Wolbachia, Cardinium, Rickettsia, and Spiroplasma are the common 
Reproductive Biology

reproductive manipulators and have a potential to alter the reproductive modes of their hosts (Hendry, Hunter, \& Baltrus, 2014; Ma, Vavre, \& Beukeboom, 2014). Four major reproductive manipulation types are distinguished: cytoplasmic incompatibility, thelytokous parthenogenesis, male killing, and feminization. In this review, the effects of these manipulation types and how they interfere with arthropod sex determination in terms of host developmental timing, alteration of sex determination, and modification of sexual differentiation pathways are summarized. Transitions between different manipulation types occur frequently which suggests that they are based on similar molecular processes. It is also discussed how mechanisms of reproductive manipulation and host sex determination can be informative on each other, with a special focus on haplodiploidy. Future directions on how the study of endosymbiotic manipulation of host reproduction can be key to further studies of arthropod sex determination are shown including cytoplasmic incompatibility, male-killing, feminization, and parthenogenetic development, and can provide host protection against some viruses and other pathogens. Wolbachia differ from many other primary endosymbionts in arthropods because they undergo frequent horizontal transmission between hosts and are well known for an abundance of mobile elements and relatively high recombination rates. Some of the endosymbionts have stimulated thelytokous reproduction mode and enforced to produce female progenies by causing cytoplasmic incompatibility, thelytokous parthenogenesis, male killing and feminization (Arakaki et al, 2001; Nguyen, 2015). Reproductive biology of thrips species in the same field changed across years, which suggesting external factor that caused to manipulate the reproductive modes of thrips. To address the latter, this external factor might be the endosymbiotic bacteria, environmental mediated reproductive mode or genetic disorder of the female.

The main goal of this paper is to provide information from research literature about the reproductive biology of thrips species, potential reproductive manipulators and their strategies to change the reproductive biology of thrips species.

\section{Reproductive modes of Thysanoptera}

Arrhenotokous and thelytokous reproductive modes are a common phenomenon in many thrips species in the world (Table 1). However, deuterotokous reproductive mode is a relatively uncommon phenomenon for thrips species since it has been reported only for A. apteris (Strauss \& Karban, 1994) and T. tabaci (Nault et al, 2006; Woldemelak, 2020).

\section{Genetically inherited reproductive modes in Thysanoptera}

Genetically inherited sex determination has become incredibly diversified and causing rapid change during evolution. According to Werren \& Beukeboom (1998) report genetic conflict has played a vital role as the driving force of this diversity and turnover.

There are two basic forms of genetic conflict. Intragenomic conflict involves conflicting selective pressures between different genetic elements within an individual organism such as between cytoplasmic genes and autosomal genes. Intergenomic conflict occurs between genetic elements in different individuals that interact over 
a particular phenotype. The genetic conflict occurred at a time of cell division while different parts of genetic systems are subjecting to line up in opposite directions. This conflict might be happening between paternal and maternal or within the genomes such as between cytoplasmic and nuclear genes or sex chromosomes and autosomes (Partridge \& Hurst, 2003). Sex chromosomes are chromosomes needed for sex determination (male and female) and autosomes are all the rest of the chromosomes that are not needed for sex determination. Normark (2003) stated that three major classes of insect genetic sex determination systems. These are: a) diploid males (diplodiploidy), b) haploid males (haplodiploidy), and c) thelytoky.

Table 1. The reproductive modes of some Thysanopteran insect species.

\begin{tabular}{|c|c|c|}
\hline Thrips species & Reproductive biology & Authors and years \\
\hline Aeolothrips vittatus & Thelytoky & (Morison, 1947) \\
\hline Akainothrips citritarsus & Arrhenotoky & (Wrensch \& Ebbert, 1993) \\
\hline Anaphothrips obscurus & Thelytoky & (Morison, 1947) \\
\hline Anaphothrips striatus & Arrhenotoky & (Risler \& Kempter, 1961) \\
\hline Anaphothrips sudanensis & Arrhenotoky & (Tikader, 1966) \\
\hline Anthothrips niger & Arrhenotoky & (Risler \& Kempter, 1961) \\
\hline Apterothrips apteris & Arrhenotoky Thelytoky Deuterotoky & (Strauss \& Karban, 1994) \\
\hline Aptinothrips rufus & Arrhenotoky & (Sharga, 1933; Morison, 1947) \\
\hline Caliothrips indicus & Thelytoky & (Ananthakrishnan, 1990) \\
\hline Caliothrips fasciatus & Arrhenotoky & (Rugman-Jones et al, 2012; Lewis, 1973) \\
\hline Chirothrips manicatus & Arrhenotoky & (Risler \& Kempter, 1961) \\
\hline Chirothrips mexicanus & Arrhenotoky & (Balu \& Daniel, 1987; Ananthakrishnan \& Daniel, 1981) \\
\hline Chaetanaphothrips orchidii & Arrhenotokoy Thelytoky & (Pelikan, 1954; Lewis, 1993) \\
\hline Echinothrips americanus & Arrhenotoky & (Li et al, 2012) \\
\hline Euthrips tritici & Arrhenotoky & (Risler \& Kempter, 1961) \\
\hline Frankliniella fusca & Arrhenotoky & (Newsom, 1953) \\
\hline Frankliniella insularis & Arrhenotoky & (Davidson \& Bald, 1931) \\
\hline Frankliniella oxidentalis & Arrhenotoky & (Wang et al, 2014) \\
\hline Frankliniella schultzei & Arrhenotoky Thelytoky & (Gikonyo et al, 2016) \\
\hline Frankliniella tritici & Arrhenotoky & (Ananthakrishnan, 1990) \\
\hline Gynaikothrips ficorum & Arrhenotoky & (Wrensch \& Ebbert, 1993) \\
\hline Haplothrips niger & Arrhenotoky & (Loan \& Holdaway, 1955) \\
\hline Haplothrips subtilissimus & Thelytoky & (Putman, 1942) \\
\hline Haplothrips niger & Arrhenotoky Thelytoky & (Ananthakrishnan, 1990) \\
\hline Haplothrips simplex & Arrhenotoky & (Paccagnini et al, 2006) \\
\hline Haplothrips statices & Arrhenotoky & (Ananthakrishnan, 1990) \\
\hline Haplothrips statices & Arrhenotoky & (Risler \& Kempter, 1961) \\
\hline Haplothrips tritici & Thelytoky & (Ananthakrishnan, 1990) \\
\hline
\end{tabular}


Reproductive Biology

Table 1. Continued.

\begin{tabular}{|c|c|c|}
\hline Thrips species & Reproductive biology & Authors and years \\
\hline Haplothrips verbasci & Arrhenotoky & (Lewis, 1973) \\
\hline Heliothrips haemorrhoidalis & Thelytoky Arrhenotoky & $\begin{array}{l}\text { (Morison, 1947; Lewis, 1973; Han et al, } \\
\text { 2011; Hamilton, 1967) }\end{array}$ \\
\hline Helionothrips errans & Thelytoky & (Lewis, 1993) \\
\hline Hercinothrips femoralis & Thelytoky & (Kumm \& Moritz, 2008) \\
\hline Hoplothrips pedicularius & Arrhenotoky & (Otte, 1979; Wrensch \& Ebbert, 1993) \\
\hline Hoplothrips fungi & Arrhenotoky & Wrensch \& Ebbert, 1993) \\
\hline Hoplothrips ulmi & Arrhenotoky & (Otte, 1979) \\
\hline Katothrips tityrus & Arrhenotoky & (Wrensch \& Ebbert, 1993) \\
\hline Kladothrips rugosis & Arrhenotoky & (Wrensch \& Ebbert, 1993) \\
\hline Koptothrips dyskritus & Arrhenotoky & (Wrensch \& Ebbert, 1993) \\
\hline Koptothrips flavicornis & Arrhenotoky & (Wrensch \& Ebbert, 1993) \\
\hline Kurtomathrips morilli & Thelytoky & (Ananthakrishnan, 1990) \\
\hline Leucothrips nigripennis & Thelytoky & (Lewis, 1993) \\
\hline Limothrips cerealium & Arrhenotoky & (Sharga, 1933) \\
\hline Limothrips denticornis & Arrhenotoky & (Wrensch \& Ebbert, 1993; Hamilton, 1967) \\
\hline Microcephalothrips abdominalis & Arrhenotoky & (Ananthakrishnan, 1990) \\
\hline Onychothrips arotrum & Arrhenotoky & (Wrensch \& Ebbert, 1993) \\
\hline Oncothrips tepperi & Arrhenotoky & (Wrensch \& Ebbert, 1993) \\
\hline Onychothrips tepperi & Arrhenotoky & (Wrensch \& Ebbert, 1993) \\
\hline Parthenothrips dracaenae & Arrhenotoky Thelytoky & (Ananthakrishnan, 1990; Morison, 1947) \\
\hline Pseudoarticulella obscurus & Thelytoky & (Morison, 1947) \\
\hline Rhipiphorothrips cruentatus & Arrhenotoky & (Ananthakrishnan, 1990) \\
\hline Rhopalothripoides froggatti & Arrhenotoky & (Wrensch \& Ebbert, 1993) \\
\hline Sciothrips cardamom & Arrhenotoky & (Ananthakrishnan, 1990) \\
\hline Scirtothrips bispinoslls & Arrhenotoky & (Ananthakrishnan, 1990) \\
\hline Scirtothrips citri & Arrhenotoky & (Lewis, 1973) \\
\hline Scirtothrips dorsalis & Arrhenotoky & (Ananthakrishnan, 1990) \\
\hline Scirtothrips longipennis & Thelytoky & (Lewis, 1993) \\
\hline Scirtothrips perseae & Arrhenotoky & (Hoddle, 2002) \\
\hline Scolothrips sexmaculatus & Arrhenotoky & (Coville \& Allen, 1977) \\
\hline Taeniothrips vulgatissimus & Arrhenothrips & (Lewis, 1993) \\
\hline Taeniothrips inconsequens & Arrhenotoky & (Davidson \& Bald, 1931) \\
\hline Thrips linarius & Arrhenotoky & (Lewis, 1973) \\
\hline
\end{tabular}


Table 1. Continued.

\begin{tabular}{|l|l|l|}
\hline Thrips species & Reproductive biology & Authors and years \\
\hline Thrips nigropilosus & $\begin{array}{l}\text { Arrhenotoky } \\
\text { Thelytoky }\end{array}$ & (Morison, 1947; Nakao \& Yabu, 1998) \\
\hline Thrips calcaratus & Thelytoky & (Parker et al, 1995) \\
\hline Thrips tabaci & $\begin{array}{l}\text { Arrhenotoky Thelytoky } \\
\text { Deuterotoky }\end{array}$ & $\begin{array}{l}\text { (Jacobson et al, 2013; Li et al, 2014; 2015 Nault et } \\
\text { al, 2006; Woldemelak, 2020) }\end{array}$ \\
\hline Warithrips maelzeri & Arrhenotoky & (Wrensch \& Ebbert, 1993) \\
\hline Xaniothrips leukandrus & Arrhenotoky & (Wrensch \& Ebbert, 1993) \\
\hline Xaniothrips xantes & Arrhenotoky & (Wrensch \& Ebbert, 1993) \\
\hline Zaniothrips ricini & Arrhenotokous & (Ananthakrishnan, 1990) \\
\hline
\end{tabular}

\section{Diplodiploidy sex determination}

In this system, the full cycle of meiosis and a fusion of two cells is involved in each generation. Both the father and mother give a haploid set of chromosomes to each offspring and therefore, the maternally and paternally derived chromosome regions have equal probabilities of being presented (Normark, 2003). Every male progeny genetically shares one haploid genome from his mother and one haploid genome from his father by default. Thus, all the offspring carry a diploid genome. Diplodiploidy sex determination mechanism has been reported in the large majority of insect orders except Thysanoptera and Hymenoptera (Normark, 2003). Diploid male have been reported in the arrhenotokous T. tabaci (Jacobson et al, 2016). However, this report has failed to explain the ploidy level of the next generation. It did not give an answer whether these diploid males are fertile or not. Thus, it is difficult to conclude that Thysanoptera insect species have diplodiploidy genome size.

\section{Haplodiploid sex determination}

Haplodiploidy is a genetically inherited sex determination system and the well-known form of haplodiploidy is arrhenotokous haplodiploidy. Insect species in the order of Thysanoptera usually have haplodiploidy reproductive mode, since the majority of the species are arrhenotoky (Ananthakrishnan, 1990). However, there are some few thrips species, which produce only female progeny by thelytoky reproduction mode. In this sex determination system, the male genes do not carry the paternal genome and all of the parental sperm cell allowed to transfer an identical band of maternal chromosomes to the offspring (Haig, 1993; Kuijper \& Pen, 2010). The haploid male progeny that produced from the mated female did not pass through the meiosis cell division process (Brown 1963; Goldstein, 1994). The haplodiploid sons do not carry traits from their fathers but the maternal grandfathers are their closest male progenitors (Filia et al. 2015). The following sex determination models has reported in some of the Insecta orders.

Arrhenotokous haplodiploidy (Arrhenotoky): Every male produced from an unfertilized egg and has only a haploid genome inherited from his mother (Ananthakrishnan, 1990). It is not only found in Thysanoptera, but also in Hymenoptera, Hemiptera, and Coleoptera (Heimpel \& Boer, 2008) in which diploid females develop 
from fertilized eggs and haploid males develop from unfertilized eggs. We discuss recent progress in the understanding of the genetic and cytoplasmic mechanisms that make arrhenotoky possible. The best-understood mode of sex determination in the Hymenoptera is complementary sex determination (CSD). Hartl \& Brown (1970) the factor is assumed to be an environmental variable; in the other model the factor is a newly mutated gene. In both cases there follows a population in which haploid males and diploid males coexist.

Paternal genome elimination (PGE): "it is a subset of haplodiploidy in which females and males develop from fertilized eggs, then subsequently the paternal genome set is eliminated" (Heimpel and Boer 2008) in which diploid females develop from fertilized eggs and haploid males develop from unfertilized eggs. The best-understood mode of sex determination in the Hymenoptera is complementary sex determination (CSD). Lastly the male carries only haploid genes from his mother (Filia, Bain, \& Ross, 2015). It is reported mainly in Hemiptera, Coleoptera, and Diptera insect orders (Heimpel \& Boer, 2008) in which diploid females develop from fertilized eggs and haploid males develop from unfertilized eggs. However, it did not get research attention from Thysanoptera insect species. In haplodiploid species, three types of paternal genome elimination are reported (Filia et al; 2015). Such as a) (N) haploid male in which the male is produced from an unfertilized egg. b) $(2 \mathrm{~N})$ in which the zygote is formed from the half-paternal and half maternal genome, yet during cleavage the paternal genomes are eliminated and only the maternal genome is transmitted through male sperm. c) $\left(2 \mathrm{~N}^{*}\right)$ where the paternal genome has transcriptionally silenced in somatic cells and $\mathrm{N}$ for embryonic PGE.

\section{Thelytokous}

It is a type of parthenogenetic reproduction mode. The females transmit only maternal genes and produce only daughters. In another word, it favours the unfertilized eggs that develop into females. In this reproduction mode, there is a complete lack of males. Either genetically inherited or intracellular bacteria determine this reproductive mode. The major features of thelytoky reproduction biology are: (a) reproductive efficiency, (b) there is no energy wastage for mating and (c) a lack of recombination between the genomes of different individuals. In thelytokous reproduction system the individual ploidy level is varied. The thelytokous $T$. tabaci strain comprises of a diploid and tetraploid genome (Jacobson et al, 2013; 2016). The polyploidy genome might be favouring the thelytokous reproduction mode (Nguyen et al, 2015). In haplodiploid insects, thelytoky can be encoded in their genomes, or induced by maternally inherited bacteria such as Wolbachia or Cardinium. Microbially facilitated thelytoky usually results in complete homozygosity due to gamete duplication and can be reverted into arrhenotoky, the parthenogenetic development of males, through treatment with antibiotics. In contrast, genetically encoded thelytoky cannot be removed and may result in conservation of heterozygosity due to gamete fusion. There are two major cytoplasmic mechanisms to induce thelytokous parthenogenesis and both resulting diploid individuals, such as automictic and apomictic thelytokous. 
Automictic thelytoky: It follows a meiosis cell division process where a new progeny obtained from a product of single meioticaly dividing cell, crossing over during meiosis retained, and diploid eggs formed by the fusion of sister or non-sister nuclei containing recombinant chromosomes (Mogie, 1986; Heimpel \& Boer, 2008). Gamete duplication goes homozygous after one generation. Likely, recombination does not have any impression on the distribution of the numbers of deleterious mutations per individual (Haccou \& Schneider, 2003) only a few specific reproductive modes are considered in the search of explanations for the maintenance of sex. There are, however, many alternatives. Including these may give radically different conclusions. The theory on deterministic deleterious mutations states that in large populations segregation and recombination may lead to a lower load of deleterious mutations, provided that there are synergistic interactions. Empirical research suggests that effects of deleterious mutations are often multiplicative. Such situations have largely been ignored in the literature, since recombination and segregation have no effect on mutation load in the absence of epistasis. However, this is true only when clonal reproduction and sexual reproduction with equal male and female ploidy are considered. We consider several alternative reproductive modes that are all known to occur in insects: arrhenotoky, paternal genome elimination, apomictic thelytoky, and automictic thelytoky with different cytological mechanisms to restore diploidy (Haccou \& Schneider, 2003). Diploidy is regenerated during or after meiosis and chromosome number may be doubled during the first mitotic division following meiosis and giving rise to diploid eggs that are homozygous at all loci (Engelsta, 2008). Mostly automictic thelytoky is common in Hymenoptra insects and the diploid female is obtained by terminal fusion, central fusion and gamete duplication (Stenberg \& Saura, 2009; Rabeling \& Kronauer, 2013).

Apomictic thelytoky: It is a mitotic parthenogenetic reproduction, thus it does not require full meiosis cell division and fusion of meiotic cell products. The eggs are formed through complete suppression of meiosis and the developed progenies are genetically identical to their maternal (Engelsta, 2008). The egg cell is produced through mitotic and consequently the progenies consist of identical genomes to their mother (Rabeling \& Kronauer, 2013). Exclusively one cell division mastered during the mitosis process and the number of chromosomes has not reduced. The diploid females obtained from the true clones of the mother due to the lack of genetic recombination. Over time, mutations are thought to accumulate independently in the two alleles at any given locus, leading to genetic divergence and high levels of heterozygosity in ancient apomictic lineages (Welch \& Meselson, 2000). However, ameiotic recombination in apomictic lineages can lead to the loss of heterozygosity, which can have a substantially stronger effect on genome evolution than the accumulation of mutations can (Omilian, Cristescu, Dudycha, \& Lynch, 2006). It is common in aphids, the beetle Micromalthus, cecidomyid midges and cynipid wasps (Stenberg \& Saura, 2009).

\section{Sex determinant endosymbionts}

Endosymbionts are living microorganisms, which inhabit within the body and cells of living organisms. The interaction between hosts and intracellular endosymbionts 
is commonly found in many arthropods species (Douglas, 1998; Newton et al, 2016). Endosymbionts are reproducing within the generative cells such as sperm and ovaries of the host and persist mutually for a prolonged period of time (Weinert, Araujo-Jnr, Ahmed, \& Welch, 2015). The interaction between endosymbionts and host insect species induce reproductive changes of the host (Weeks, Velten, \& Stouthamer, 2003; Kageyama, Narita, \& Watanabe, 2012). Recent evidence suggests that another intracellular bacterium, a Cytophaga-like organism (CLO) and improve the survival rate and evolution of the hosts (Moran \& Telang, 1998). Some of the endosymbionts induce parthenogenetic thelytokous reproduction (Arakaki et al, 2001; Huigens, De Almeida, Boons, Luck, \& Stouthamer, 2004; Nguyen, 2015). Occasionally, these symbiotic bacteria manipulate the reproductive biology of the hosts to enhance their own transmission and reduce the gene flow between populations and they allow genetic divergence for locally adaptive strains (Engelsta \& Telschow, 2009). In spider mites, the prevalence of endosymbiotic bacteria is significantly more common in females than males, suggesting it might be behaving as a sex-ratio distorter (Duron, Hurst, Hornett, Josling, \& Engelstädter, 2008).

\section{The major parthenogenesis inducing endosymbionts}

Wolbachia, Cardinium, Rickettsia, and Spiroplasma are the common parthenogenesis inducing endosymbionts for various insects and completely ascertain the reproductive biology of the hosts (Hendry, Hunter, \& Baltrus, 2014; Ma et al, 2014). Endosymbionts, such as Wolbachia, Cardinium, Rickettsia, and Spiroplasma, can manipulate host reproduction. Four major reproductive manipulation types are distinguished: cytoplasmic incompatibility, thelytokous parthenogenesis, male killing, and feminization. In this review, the effects of these manipulation types and how they interfere with arthropod sex determination in terms of host developmental timing, alteration of sex determination, and modification of sexual differentiation pathways are summarized. Transitions between different manipulation types occur frequently which suggests that they are based on similar molecular processes. It is also discussed how mechanisms of reproductive manipulation and host sex determination can be informative on each other, with a special focus on haplodiploidy including cytoplasmic incompatibility, male-killing, feminization, and parthenogenetic development, and can provide host protection against some viruses and other pathogens. Wolbachia differ from many other primary endosymbionts in arthropods because they undergo frequent horizontal transmission between hosts and are well known for an abundance of mobile elements and relatively high recombination rates.

Wolbachia is a member of Alphaprotoeobacteria class and the most desirable and abundant parthenogenesis-inducing endosymbiont that determines the reproductive biology of its hosts (Yen \& Barr, 1971). There are two main kinds of Wolbachia (A and B) that diverged from 58 to 67 million years before present based upon synonymous substitution rates (Werren, Zhang, \& Guo, 1995).

The parthenogenesis-inducing bacteria favour female-biased offspring (Engelsta \& Telschow, 2009). When Wolbachia-infected male sperm fertilized the uninfected 
female egg: (1) it caused to fail the first division of the new embryo, (2) the male chromosomes never completely condensed to proceed meiosis cell division and (3) after all, it caused to divide the male chromosome improperly (Nguyen, 2015). It seems that sperm from infected male hold a factor to interfere with male cell divisions and resulting early death of male embryos and only allows the cell division to produce a parthenogenetic female. Similarly, the Wolbachia-free female coupled with infected male fails to develop male progeny (Yishay, 2009).

Most likely, a parthenogenetic female sex manipulator endosymbionts are common in the major insect orders such as Hymenoptera, Coleoptera, Diptera, Hemiptera, Lepidoptera, and Orthoptera. However, the overall extent of Wolbachia prevalence is higher in Hymenoptera insect order than in the others (Werren et al, 1995). A recent report showed that Wolbachia bacteria has induced the reproduction biology of Thysanoptera insect order (Nguyen, Morrow, Spooner-Hart, \& Riegler, 2017)yet interactions between both bacterial endosymbionts are rarely studied.

Table 2. Reproductive manipulating endosymbionts in thrips species.

\begin{tabular}{|l|l|l|}
\hline Thrips species & Types of bacteria evolved & Author and year \\
\hline Aptinothrips rufus & Wolbachia & (Van der Kooi \& Schwander, 2014) \\
\hline Caliothrips fasciatus & Wolbachia & (Rugman-Jones et al, 2012) \\
\hline Echinothrips americanus & Wolbachia & (Kumm \& Moritz, 2008) \\
\hline Franklinothrips vespiformis & Wolbachia & (Arakaki et al, 2001) \\
\hline Gynaikothrips ficorum & Wolbachia & (Kumm \& Moritz, 2008) \\
\hline Heliothrips haemorrhoidalis & Wolbachia & (Koivisto \& Braig, 2003) \\
\hline Hercinothrips femoralis & Wolbachia & (Kumm \& Moritz, 2008) \\
\hline Parthenothrips dracaenae & Wolbachia & (Kumm \& Moritz, 2008) \\
\hline Pezothrips kellyanus & Cardinium & (Nguyen et al, 2017) \\
\hline Suocerathrips linguis & Wolbachia & (Kumm \& Moritz, 2008) \\
\hline Sciothrips cardamomi & Wolbachia & (Jacob et al, 2014) \\
\hline Thrips palmi & Wolbachia & (Saurav et al, 2016) \\
\hline Thrips tabaci & Wolbachia & (Gawande et al, 2019) \\
\hline
\end{tabular}

\section{Endosymbionts strategies to manipulate the reproduction biology of their hosts}

The endosymbionts are using various strategies to distort the reproduction biology of their hosts and enhance their own transmission to the next generation. Among them cytoplasmic incompatibility, thelytokous parthenogenesis, male killing and feminization are the most common strategies (Neill, Giordano, Colbert, Timothy, \& Robertson, 1992; Schilthuizen et al, 1992; Cook \& Butcher, 1999; Bandi, Dunn, Hurst, \& Rigaud, 2001; Koivisto \& Braig, 2003; Dale \& Moran, 2006; Hendry et al, 2014; Ma et al, 2014; Newton et al, 2016) such as female-biased sex ratios, parthenogenesis, and sterility of crosses either between infected males and uninfected females or between infected individuals (Weeks et al, 2003; Zabalou et al, 2004; Yishay, 2016). These strategies are providing 
Reproductive Biology

them either to produce more females or to cause uninfected females reproductively incompatible with infected males (Nguyen et al, 2017) yet interactions between both bacterial endosymbionts are rarely studied.

\section{Cytoplasmic Incompatibility (Cl)}

$\mathrm{Cl}$ is the process that causes the mating of male and female ineffective to develop the feasible progeny. It results from modification in the gamete cells caused by intracellular endosymbiotic bacteria. It has been reported for six insect orders (Coleoptera, Diptera, Hemiptera, Hymenoptera, Lepidoptera, and Orthoptera) and terrestrial crustaceans and mites (Ma et al, 2014). The co-infect of Wolbachia and Cardinium causes $\mathrm{Cl}$ in Thysanoptera insect species (Nguyen et al, 2017).

Endosymbiotic bacteria induce $\mathrm{Cl}$ in two ways, such as unidirectional and bidirectional. In the first hand, unidirectional cytoplasmic incompatibility is resulted from crossing between infected male and uninfected female. Unidirectional $\mathrm{Cl}$ has led to the death of embryos while the infected male mate with the uninfected female (Breeuwer \& Werren, 1990; O'neill \& Karr, 1990). On the other hand, bidirectional cytoplasmic incompatibility occurred while the infected male mates with a female infected by a different strain of endosymbiont (Merqot, Liorente, Jacques, Atlan, \& Montchamp-Moreau, 1995; Perrot-Minnot, Guo, \& Werren, 1996). Cytological studies reported that during incompatible crosses: the paternal chromosomes do not condense, harmed and eventually are lost during the first mitotic divisions (Callaini, Dallai, \& Riparbelli, 1997; Tram, Sullivan, Tram, \& Sullivan, 2002). However, viable offspring can produce from both unidirectional and bidirectional cytoplasmic incompatibility if both parents genes are infected by the same endosymbiotic bacterial strain. Cytoplasmically incompatible genes have no biological involvement for the male development; rather it enhances male evolutionary dead-end (Hurst \& Parks, 1993). Thus, a bacteria permits its host to develop female-biased offspring (Partridge and Hurst 2003).

The endosymbiotic bacteria has caused delayed the paternal chromatin condensation and allowed the maternal chromosomes to anaphase cell division process. Among these bacterial species, Wolbachia bacteria is one of the most common genus that leads to disruption of the condensation of crossing the cytoplasmically incompatible strains of parental chromatin compliments. This effect has been well studied in the wasp Nasonia vitripennis and Drosophila simulans (Ryan \& Saul, 1968; O'Neill \& Karr, 1990; Callaini et al, 1997). For normal cell division, both the maternal and paternal chromosomes line up on the middle of the equator and both chromosomes would be passed to the anaphase stage. Whereas, the infected paternal chromosomes have condensed improperly and delayed at the metaphase plate, but female chromatids have accomplished anaphase plate and migrated to the opposite poles of the spindle. This delay at the anaphase stage has led to dramatic errors in paternal chromatin inheritance.

\section{Thelytokous parthenogenesis}

Reversible or microbe-induced and irreversible thelytoky are the two parthenogenetic thelytokous that induced by endosymbiotic microbes (Stouthamerff \& Kazmert, 
1994). High temperature did not affect sex allocation ratios in either thelytokous or male-producing $T$. tabaci populations (Nault et al, 2006). In the reversible thelytoky, male produced after the removal of microbes via high temperature or antibiotic treatment. Whereas, the irreversible thelytoky endosymbiotic bacteria is not detected and neither high temperature nor antibiotic treatment induces the production of males (Stouthamer, Luck, \& Hamilton, 1990).

\section{Male killing}

Maternally inherited endosymbionts has been reported to distort the male embryo in a broad range of insect host species (Hurst \& Jiggins, 2000). They can distort the sex ratio of their hosts by killing the infected male offspring (Groenenboom \& Hogeweg, 2002). Hurst (1991) stated that there are two types of male-killing cytoplasmic genes characterized by their time of activity. (1) Early male killer:- it affects the embryo and kill the male gene at embryo stage. Male killing at embryo stage has been reported in Diptera, Hymenoptera, Coleoptera, Lepidoptera, and Hemiptera insect orders. However, there is no research report for thrips species. (2) Late male killer: - the male dies at the fourth instar larval developmental stage and most commonly observed only in mosquitoes.

Hurst \& Majerus (1993) reviewed three evolutionary advantages why maternally inherited microorganisms do kill the male. First, killing males may produce enough food resources to sibling females that bear a clonal relative of the bacterium. Such an enhancement in resources availability might be either direct, from permitting the consumption of the soma of male eggs, or indirect, from the reduction of competition suffered by sisters of such individuals. Such resource reallocation conceived to increase the fitness of the daughters, the line through which the microbe may pass itself vertically. Second, avoidance of inbreeding, females, which bear the microbe, will have few if any brothers, and are thus less likely to inbreed. Their daughters are thus less likely to suffer from inbreeding depression. Third, male's death may be a mechanism to produce the horizontal transfer of the microbe out of the male lineage, through which it cannot passes vertically, into other organisms (Higashiura, Ishihara, \& Schaefer, 1999).

The endosymbiotic bacteria is transmitting to its host insect through vertical and horizontal pathways (Huigens et al, 2004). The vertical transmission pathway displays the major way of endosymbiotic transmission from mother to offspring (Hoffmann et al, 1990; Bandi et al, 2001). The hereditary bacteria infect the offspring at the time of embryogenesis process and the progeny emerged with cytoplasmic inducing bacteria. Whereas in the horizontal mode of transmission the infection of endosymbionts happens between interspecies and the infection might be happening during feeding.

\section{CONCLUSION AND FUTURE RESEARCH REMARKS}

Thysanoptera insect species prominently reproduced by arrhenotoky, thelytoky and occasionally deuterotoky. Arrhenotokous (male produced from the unfertilized eggs), thelytokous (virgin females produce only female progenies or female progenies are 
producing from unfertilized eggs) and deuterotoky (virgin female produce both male and female). Thysanoptera order insect species usually pointed out haplodiploid sex determination.

Endosymbionts exhibit a vital role to change the evolutionary biology of their hosts and trigger parthenogenetically thelytokous reproduction mode. Wolbachia, Cardinium, Rickettsia and Spiroplasma are the most common parthenogenic endosymbionts and have a potential to change the reproduction biology of some thrips species. Most likely, Wolbachia bacteria exhibit the highest percentages to infect the arthropod insect species and induces to produce female sex-biased offspring. These endosymbionts have used reproductive manipulating strategies such as cytoplasmic incompatibility, thelytokous parthenogenesis, male killing, and feminization. Apomictic and automictic thelytokous reproduction might manipulate the sex of thrips species. The role of these two genetically thelytokous inducing and the role ploidy levels in the sex determination of thrips species would be the future research area.

\section{REFERENCES}

Ananthakrishnan, T. (1990). Reproductive biology of thrips. Indira Publishing House USA, pp 4-16.

Ananthakrishnan, T. \& Daniel, A. (1981). Behavioural components in feeding, reproduction and dispersal of the grass seed-feeeding Thrips chirthrips mexicanus crawfolrd. Current Science, 50, 733-735.

Arakaki, N., Miyoshi, T., \& Noda, H. (2001). Wolbachia-mediated parthenogenesis in the predatory thrips Franklinothrips vespiformis (Thysanoptera: Insecta). Proceedings of the Royal Society B: Biological Sciences, 268(1471), 1011-1016.

Balu, A. \& Daniel, M. (1987). Eco-behavioural and biological studies on two species of seed infesting thrips (Thyasanoptera: Insecta). Proceedings: Animal Sciences, 96(1), 23-32

Bandi, C., Dunn, A.M., Hurst, G.D.D., \& Rigaud, T. (2001). Inherited microorganisms, sex-specific virulence and reproductive parasitism. Trends in Parasitology, 17(2), 88-94

Breeuwer, J.A.J., \& Werren, J.H. (1990). Microorganisms associated with chromosome destruction and reproductive isolation between insect species. Nature, 346, 558-560.

Brown, S. (1963). Automatic frequency response in the evolution of male haploidy and other coccid chromosome systems. Genetics, 49,797-817.

Callaini, G., Dallai, R., \& Riparbelli, M.G. (1997). Wolbachia-induced delay of paternal chromatin condensation does not prevent maternal chromosomes from entering anaphase in incompatible crosses of Drosophila simulans. Journal of Cell Science, 110(2), 271-280.

Cook, J.M., Butcher, R.D.J. (1999). The transmission and effects of Wolbachia bacteria in parasitoids. Researches on Population Ecology, 41(1), 15-28.

Coville, P.L. \& Allen, W.W. (1977). Life table and feeding habits of Scolothrips sexmaculatus (Thysanoptera: Thripidae). Annals of the Entomological Society of America, 70(1), 11-16.

Dale, C. \& Moran, N.A. (2006). Molecular interactions between bacterial symbionts and their Hosts. Cell, 126(3), 453-465. https://doi.org/10.1016/j.cell.2006.07.014

Davidson, J. \& Bald, J. (1931). Sex determination in Frankliniella insularis (Thysanoptera). The Australian Journal of Experimental Biology and Medical Science, 8(2), 139-142.

Douglas, A.E. (1998). Nutritional interactions in insect-microbial symbiosis: Aphids and their symbiotic bacteria Buchnera. Annual Review of Entomology, 43(1), 17-37.

Duron, O., Hurst, G.D.D., Hornett, E.A., Josling, J.A., \& Engelstädter, J. (2008). High incidence of the maternally inherited bacterium Cardinium in spiders. Molecular Ecology, 17(6), 1427-1437. 
Engelsta, J. (2008). Constraints on the evolution of asexual reproduction. Bio Essays, 30(11-12), 1138-1150. https://doi.org/10.1002/bies.20833

Engelsta, J. \& Telschow, A. (2009). Cytoplasmic incompatibility and host population structure. Heredity, 103(3), 196-207.

Engelstädter, J. \& Hurst, G. D. (2009). The ecology and evolution of microbes that manipulate host reproduction. Annual Review of Ecology Evolution and Systematics, 40, 127-149.

Filia, G.D., Bain, S.A., \& Ross, L. (2015). Haplodiploidy and the reproductive ecology of arthropods. Current Opinion in Insect Science, 9, 36-43.

Gawande, S.J., Anandhan, S., Ingle, A., Roylawar, P., Khandagale, K., Gawai, T., \& Singh, M. (2019). Microbiome profiling of the onion thrips, Thrips tabaci Lindeman (Thysanoptera: Thripidae). PloS one, 14(9), e0223281.

Gikonyo, M.W., Niassy, S., Moritz, G.B., Khamis, F.M., Magiri, E., \& Subramanian, S. (2016). Resolving the taxonomic status of Frankliniella schultzei (Thysanoptera: Thripidae) colour forms in Kenya a morphological-, biological-, molecular- and ecological-based approach. International Journal of Tropical Insect Science, 37(02), 57-70. Doi: 10.1017/s1742758416000126

Goldstein, D.B. (1994). Deleterious mutations and the evolution of male haploidy. The American Naturalist, 144(1), 176-183.

Groenenboom, M.A.C. \& Hogeweg, P. (2002). Space and the persistence of male-killing endosymbionts in insect populations. Proceedings of the Royal Society B: Biological Sciences, 269(1509), 2509-2518. doi:10.1098/rspb.2002.2197.

Haccou, P. \& Schneider, M.V. (2003). Modes of reproduction and the accumulation of deleterious mutations with multiplicative fitness effects. Genetics, 166(2), 1093-1104. https://doi.org/10.1534/ genetics.166.2.1093

Haig, D. (1993). The evolution of unusual chromosomal systems in coccoids: extraordinary sex ratios revisited. Journal of Evolutionary Biology, 6(1), 69-77.

Hamilton, W.D. (1967). Extraordinary sex ratios. Science, 156(3774), 477-488.

Han, F., Liu, X.X., Tian, J.C., Zhang, Q.W., \& Shelton, A. (2011). A new source of cabbage host plant resistance to the diamondback moth (Lepidoptera: Plutellidae). Florida Entomologist, 94(3), 711-714

Hartl, D. \& Brown, S. (1970). The origin of male haploid genetic systems and their expected sex ratio. Theoretical Population Biology, 1, 165-190.

Heimpel, G.E. \& De Boer, J.G. (2008). Sex determination in the Hymenoptera. Annual Review of Entomology, 53(1), 209-230.

Hendry, T.A., Hunter, M.S., \& Baltrus, D.A. (2014). The facultative symbiont Rickettsia protects an invasive whitefly against entomopathogenic Pseudomonas syringae strains. Applied and Environmental Microbiology, 80, 7161-7168.

Higashiura, Y., Ishihara, M., \& Schaefer, P.W. (1999). Sex ratio distortion and severe inbreeding depression in the gypsy moth Lymantria dispar L. in Hokkaido Japan. Heredity, 83(3), 290-297.

Hoddle, M.S. (2002). Developmental and reproductive biology of Scirtothrips perseae (Thysanoptera: Thripidae): a new avocado pest in California. Bulletin of Entomological Research, 92(4), 279-285.

Hoffmann, A.A., Turellit, M., \& Harshman, L.G. (1990). Factors affecting the distribution of cytoplasmic incompatibility in. Genetics Society of America, 126, 933-948.

Huigens, M.E., De Almeida, R.P., Boons, P.A.H., Luck, R.F., \& Stouthamer,R. (2004). Natural interspecific and intraspecific horizontal transfer of parthenogenesis-inducing Wolbachia in Trichogramma wasps. Proceedings of the Royal Society B: Biological Sciences, 271(1538), 509-515.

Hurst, G.D. \& Majerus, M.E. (1993). Why do maternally inherited microorganisms kill males? Heredity, 71(1), 81.

Hurst, G.D. \& Jiggins, F.M. (2000). Male-killing bacteria in insects: mechanisms, incidence, and implications. Emerging Infectious Diseases, 6(4), 329. 
Reproductive Biology

Hurst, L.D. \& Parks, S. (1993) The incidences. Mechanisms and evolution of cytoplasmic sex ratio distorters in animals. Biological Reviews, 68(1), 121-194.

Hurst, L.D. (1991). The incidences and evolution of cytoplasmic male killers. Proceedings of the Royal Society B: Biological Sciences, 244(1310), 91-99.

Hurst, L.D.(1993). The incidences. Mechanisms and evolution of cytoplasmic sex ratio distorters in animals. Biological Reviews, 68(1), 121-194

Jacob, T.K.D., Silva, S., Senthil Kumar, C.M., Devasahayam, S., Rajalakshmi, V., Sujeesh, E.S., \& Abraham, S. (2015). Single strain infection of adult and larval cardamom thrips (Sciothrips cardamomi) by Wolbachia subgroup Con belonging to super group B in India. Invertebrate Reproduction and Development, 59(1), 1-8.

Jacobson, A.L., Johnston, J.S., Rotenberg, D., Whitfield, A.E., Booth, W., Vargo, E.L., \& Kennedy, G.G. (2013). Genome size and ploidy of Thysanoptera. Insect Molecular Biology, 22(1), 12-17.

Jacobson, A.L., Nault, B.A., Vargo, E.L., \& Kennedy, G.G. (2016). Restricted gene flow among lineages of Thrips tabaci supports genetic divergence among cryptic species groups. Plos One, 11(19), e0163882.

Kageyama, D., Narita, S., \& Watanabe, M. (2012). Insect sex determination manipulated by their endosymbionts: Incidences, mechanisms and implications. Insects, 3(1), 161-199. https://doi. org/10.3390/insects3010161

Koivisto, R.K. \& Braig, H.R. (2003). Intraclonal genetic variation: ecological and evolutionary aspects. In H.D., Loxdale, G., Lushai (Eds.). Microorganisms and parthenogenesis. Biological Journal of the Linnean Society, 79(1), 43-58.

Kuijper, B. \& Pen, I. (2010). The evolution of haplodiploidy by male-killing endosymbionts: importance of population structure and endosymbiont mutualisms. Journal of Evolutionary Biology, 23(1), 40-52.

Kumm, S. \& Moritz, G. (2008). First detection of Wolbachia in arrhenotokous populations of Thrips Species (Thysanoptera: Thripidae and Phlaeothripidae) and its role in reproduction. Environmental Entomology, 37(6), 1422-1428.

Lewis, T., (1973). Thrips their biology, ecology and economic importance (pp. 36-50). London, UK: Academic Press Inc.

Li, X.W., Fail, J., Wang, P., Feng., J.N., \& Shelton, A.M. (2014). Performance of arrhenotokous and thelytokous Thrips tabaci (Thysanoptera: Thripidae) on onion and cabbage and its implications on evolution and pest management. Journal of Economic Entomology, 107(4), 1526-1534. Doi: 10.1603/ ec14070

Li, X.W., Wang, P., Fail, J., \& Shelton, A.M. (2015). Detection of gene flow from sexual to asexual lineages in Thrips tabaci (Thysanoptera: Thripidae). PLOS ONE, 10(9), 1-13

Li, X.W., Zhang, X.C., Jiang, H.X., \& Feng, J.N. (2012). Comparisons of developmental and reproductive biology between parthenogenetic and sexual Echinothrips americanus (Thysanoptera: Thripidae). Environmental Entomology, 41(3), 706-713. Doi: 10.1603/en11325

Loan, H.F.G. (1955). Biology of the red clover thrips, Haplothrips niger (Osborn) (Thysanoptera: Phloeothripidae). The Canadian Entomologist, 87(5), 210-219

Ma, W.J., Vavre, F., \& Beukeboom, L.W. (2014). Manipulation of arthropod sex determination by endosymbionts: Diversity and molecular mechanisms. Sexual Development, 8(1-3), 59-73. Doi: 10.1159/000357024

Merqot, H., Liorente, B., Jacques, M., Atlan, A., \& Montchamp-Moreau, C. (1995). Variability within the Seychelles cytoplasmic incompatibility system in Drosophila simulans. Genetics, 141(3), 1015-1023.

Mogie, M. (1986). Automixis: its distribution and status. Biological Journal of the Linnean Society, 28(3), 321-329

Moran, N.A. \& Telang, A. (1998). Bacteriocyte-associated symbionts of insects. Bioscience, 48(4), 295-304

Morison, G.D. (1947). Thysanoptera of the London area. London Naturalist, 59, 1-131 
Nakao, S. \& Yabu, S. (1998). Genetics of wing polymorphism in the arrhenotokous Thrips nigropilosus Uzel. Japan Journal of Entomology (N. S.) 1, 9-19

Nault, B.A., Shelton, A.M., Gangloff-Kaufmann, J.L., Clark, M.E., Werren, J.L., Cabrera-la Rosa, J.C., \& Kennedy, G.G (2006). Reproductive modes in onion thrips (Thysanoptera: Thripidae) populations from New York onion Fields. Environmental Entomology, 35(5), 1264-1271

Neill, S.L.O., Giordano, R., Colbert, A.M.E., Timothy, L., \& Robertson, H.M. (1992). 16S rRNA phylogenetic analysis of the bacterial endosymbionts associated with cytoplasmic incompatibility in insects. Proceedings of the National Academy of Sciences, 89(7), 2699-2702

Newsom, L.D. (1953). The tobacco thrips: its seasonal history and status as a cotton pest. LSU Agricultural Experiment Station Reports, 632.

Newton, I.L.G., Clark, M.E., Kent, B.N., Bordenstein, S.R., Qu, J., Richards, S., \& Werren, J.H. (2016). Comparative genomics of two closely related Wolbachia with different reproductive effects on hosts. Genome Biology and Evolution, 8(5), 1526-1542. Doi: 10.1093/gbe/evw096

Nguyen, D.T. (2015). Genetic diversity, reproductive systems and endosymbionts of two invasive thrips species. PhD thesis, University of Western Sydney, pp 2-12.

Nguyen, D.T., Morrow, J.L., Spooner-Hart, R.N., \& Riegler, M. (2017). Independent cytoplasmic incompatibility induced by Cardinium and Wolbachia maintains endosymbiont co-infections in haplodiploid thrips populations. Evolution, 71(4), 995-1008. Doi:10.1111/evo.13197

Nguyen, D.T., Spooner-Hart, R.N., \& Riegler, M. (2015). Polyploidy versus endosymbionts in obligately thelytokous thrips. BMC Evolutionary Biology, 15(1), 23. Doi: 10.1186/s12862-015-0304-6

Normark, B. (2003). The evolution of alternative genetic systems in insects. Annual Review of Entomology, 48(1), 397-423.

Omilian, A.R., Cristescu, M.E., Dudycha, J.L., \& Lynch, M. (2006). Ameiotic recombination in asexual lineages of Daphnia. Proceedings of the National Academy of Sciences, 103(49), 18638-18643

O'Neill, S.L. \& Karr, T.L. (1990). Bidirectional incompatibility between conspecific populations of Drosophila simulans. Nature, 348(6297), 178

Otte, D. (1979). Historical Development of sexual selection theory, sexual selection and reproductive competion in insects. Academic press INC. New York, pp 76

Paccagnini, E., De Marzo, L., Giusti, F., \& Dallai, R. (2006). The aberrant spermatogenesis of the Haplothrips simplex (Buffa) (Thysanoptera): Ultrastructural study. Tissue and Cell, 38(3), 177-186.

Parker, B.L. \& Skinner, M. (1995). Thrips biology and management. Lewis T. (Ed.). Doi:10.1007/978-14899-1409-5

Partridge, L. \& Hurst, L.D. (2003). Sex and conflict. Science, 281(5385), 2003-2008.

Pelikan, J. (1954). Remarks on the orchid thrips Chaetanaphothrips orchidii (M.). Folia Zoologica Entomologica, 3, 3-12

Perrot-Minnot, M.J., Guo, L.R., \& Werren, J.H. (1996). Single and double infections with Wolbachia in the parasitic wasp Nasonia vitripennis effects on compatibility. Genetics, 143(2), 961-972

Putman, W.L. (1942). Notes on the predaceous thrips Haplothrips subtilissimus hal. and Aeolothrips melaleucus hal. The Canadian Entomologist, 74(3), 37-43

Rabeling, C. \& Kronauer, D.J.C. (2013). Thelytokous parthenogenesis in Eusocial Hymenoptera. Annual Review of Entomology, 58(1), 273-292.

Risler, H. \& Kempter. E. (1961). Die haploidie der männchen und die endopolyploidie in einigen geweben von haplothrips (Thysanoptera). Chromosoma, 12(1), 351-361

Rugman-Jones, J., Hoddle, M., Amrich, R., Heraty, J., Stouthamer-Igel, C. \& Stouthamer, R. (2012). Phylogeographic structure, outbreeding depression , and reluctant virgin oviposition in the bean thrips, Caliothrips fasciatus (Pergande) (Thysanoptera: Thripidae), in California. Bulletin of Entomological Research, 102(06), 698-709 


\section{Reproductive Biology}

Ryan, S.L. \& Saul, G. (1968). Post-fertilization effect of incompatibility factors in Mormoniella. Molecular and General Genetics, MGG 103(1), 29-36

Saurav, G.K., Daimei, G., Rana, V.S., Popli, S., \& Rajagopal, R. (2016). Detection and localization of Wolbachia in Thrips palmi Karny (Thysanoptera: Thripidae). Indian Journal of Microbiology, 56(2), 167-171

Schilthuizen, M., Rousset, F., Bouchon, D., Pintureau, B., Juchault, P., \& Solignac, M. (1992). Wolbachia endosymbionts responsible for various alterations of sexuality in arthropods. Proceedings of the Royal Society B: Biological Sciences, 250(1328), 91-98. https://doi.org/10.1098/rspb.1992.0135

Sharga, U. (1933). Biology and life history of Limothrips cerealium haliday and Aptinothrips rufus gmelin feeding on Gramineae. Annals of Applied Biology, 20(2), 308-326. https://doi.org/10.1111/j.17447348.1933.tb07768.x

Sogo, K., Miura, K., Aizawa, M., Watanabe, T., \& Stouthamer, R. (2014). Genetic structure in relation to reproduction mode in Thrips tabaci (Insecta: Thysanoptera). Applied Entomology and Zoology, 50(1), 73-77

Stenberg, P. \& Saura, A. (2009). Cytology of asexual animals (pp. 63-74). In lost sex. Springer Dordrecht Heidelberg London New York.

Stouthamerff, R. \& Kazmert, D.J. (1994). Cytogenetics of microbe-associated parthenogenesis and its consequences for gene flow in Trichogramma wasps. Heredity, 73, 317-327.

Stouthamer, R., Luck, R.F., \& Hamilton, W.D. (1990). Antibiotics cause parthenogenetic Trichogramma (Hymenoptera/Trichogrammatidae) to revert to sex. Proceedings of the National Academy of Sciences, 87(7), 2424-2427

Strauss, S.Y. \& Karban, R. (1994). The significance of outcrossing in an intimate plant-herbivore relationship. II. Does outcrossing pose a problem for thrips adapted to the host-plant clone? Evolution, 48(2): 465-476. https://doi.org/10.2307/241010

Tikader, B.K. (1966). On the seasonal fluctuation and biology of Anaphothrips flavicinctus (Karny) on Panicum maximum in Madras. Journal of the Bombay Natural History Society, 65(1), 243-248.

Tram, U., Sullivan, W., Tram, U., \& Sullivan, W. (2002). Role of delayed nuclear envelope breakdown and mitosis in Wolbachia -Induced Cytoplasmic Incompatibility. Science, 296(5570), 1124-1126.

Van der, K.C.J. \& Schwander, T. (2014). Evolution of asexuality via different mechanisms in grass thrips (Thysanoptera: Aptinothrips). Evolution, 68(7), 1883-1893. doi:10.1111/evo.12402.

Van Wilgenburg, E., Driessen, G., \& Beukeboom, L. W. (2006). Single locus complementary sex determination in Hymenoptera: an" unintelligent" design? Frontiers in Zoology, 3(1), 1-15.

Wang, J.C., Zhang, B., Li, H., Wang, J.P., \& Zheng, C. (2014). Effects of exposure to high temperature on Frankliniella occidentalis (Thysanoptera: Thripidae), under arrhenotoky and sexual reproduction conditions. Florida Entomologist, 97(2), 504-510

Weeks, A.R., Velten, R., \& Stouthamer, R. (2003). Incidence of a new sex-ratio-distorting endosymbiotic bacterium among arthropods. Proceedings. Biological the Royal Society B: Biological sciences, 270(1526), 1857-65

Weinert, L.A., Araujo-Jnr, E.V., Ahmed, M.Z., \& Welch, J. (2015). The incidence of bacterial endosymbionts in terrestrial arthropods. Proceedings of the Royal Society B: Biological Sciences, 282(1807), 1-6

Welch, D.B.M. \& Meselson, M. (2000). Evidence for the evolution of bdelloid rotifers without sexual reproduction or genetic exchange. Science, 288(5469), 1211-1215

Werren, J.H. \& Beukeboom, L.W. (1998). Sex determination, sex ratios, and genetic conflict. Annual Review of Ecology and Systematics, 29(1), 233-261

Werren, J.H., Zhang, W., \& Guo, L.R. (1995). Evolution and phylogeny of Wolbachia: reproductive parasites of arthropods. Proceedings of the Royal Society B: Biological Sciences, 261(1360), 55-63

Woldemelak, W.A. (2020). The existence of deuterotokous reproduction mode in the T. tabaci (Thysanoptera: Thripidae) cryptic species complex. Journal of Horticultural Research, 28(1), 21-28. 
Wrensch, D., Ebbert, M. (1993). Evolution and diversity of sex ratio in insects and mites (pp 56). Chapman and Hall, New York, USA.

Yishay, R. (2016). Distribution of the bacterial symbiont Cardinium in arthropods. Molecular Ecology, 13(7), 2009-2016.

Zabalou, S., Riegler, M., Theodorakopoulou, M., Stauffer, C., Savakis, C., \& Bourtzis, K. (2004). Wolbachia-induced cytoplasmic incompatibility as a means for insect pest population control. Proceedings of the National Academy of Sciences, 101(42), 15042-15045. 